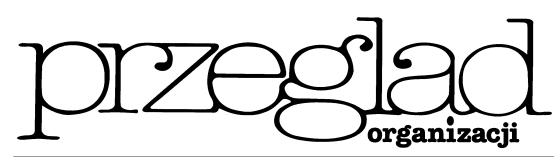

\title{
Internet jako narzędzie pracobiorcy na rynku pracy
}

https://doi.org/10.33141/po.2005.10.10

\section{Wojciech Jarecki}

\section{Wstęp}

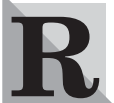
ynek pracy, szczególnie w Polsce, charakteryzuje się wysokim bezrobociem. Dotyczy ono w bardzo dotkliwym, lub wręcz patologicznym, stopniu osób młodych, będących absolwentami szkół średnich i wyższych. Mimo istnienia bogatej i wartościowej literatury opisującej zjawisko bezrobocia i licznych badań na ten temat (np. Kryńska, Suchecka, Suchecki 1998, Kabaj 2000, Kwiatkowski 2002, Skórska 2004, Góra 2005), trudno dostrzec jakieś pozytywne zmiany w ostatnich latach w jego ograniczaniu. Bez wątpienia, bezrobocie i jego zwalczanie jest zagadnieniem bardzo złożonym, wymagającym kompleksowego działania i mądrej polityki społeczno-gospodarczej.

Indywidualne osoby mają możliwość zwiększania swoich szans na rynku pracy, szczególnie poprzez kształcenie, dokształcanie czy przekwalifikowanie. Obecnie istnieją szerokie możliwości w zakresie wyboru różnych kierunków studiów czy typów szkoleń. Istotne jest, żeby były możliwości uzyskania przez zainteresowanych informacji na ten temat.

Dla osób poszukujących pracy, dla których coraz częściej problemem materialnym są koszty poszukiwania pracodawcy, ważna jest możliwość szybkiego uzyskiwania informacji o pracodawcy, kontaktowania się z nim, składania aplikacji itd. Również dla osób już pracujących, bardzo istotna jest możliwość szybkiej komunikacji z pracodawca.

Biorąc powyższe pod uwagę, podjęto w artykule problem wykorzystania internetu jako narzędzia mogacego przyczynić się do polepszenia sytuacji pracobiorców na rynku pracy. Postawiono tezę, że w Polsce niedostatecznie wykorzystuje się internet do poprawy sytuacji na rynku pracy. W celu weryfikacji tej tezy zostanie przeprowadzona analiza porównawcza między Polską i innymi krajami europejskimi, głównie Unii Europejskiej (UE) w zakresie wielkości bezrobocia, a następnie dostępności do internetu i częstości korzystania z tego narzędzia przez pracobiorców, stopnia wykorzystywania internetu do kształcenia formalnego (studia, szkoły średnie), nieformalnego (dokształcanie, szkolenia) i do polepszania bieżącej sytuacji na rynku pracy (np. poprzez składanie aplikacji, pozyskiwanie informacji o przedsiębiorstwie itd.).

Dane, które zostały zaczerpnięte z Eurostatu, dotyczą grupy szczególnie dotkniętych bezrobociem, a mianowicie osób w wieku 15-24 lata*). Poza tym, $\mathrm{z}$ tego powodu, że dużą stratą dla gospodarki i gospodarstw domowych są straty kapitału ludzkiego absolwentów szkół wyższych, którzy nie pracują, w analizie uwzględniono również studentów.
Przegląd Organizacji, Nr 10 (789), 2005, ss. 40-43 www.przegladorganizacji.pl Towarzystwo Naukowe Organizacji i Kierownictwa (TNOiK)

\section{Stopa bezrobocia}

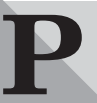

unktem wyjścia do odpowiedzi na przedstawione wyżej problemy może być analiza stopy bezrobocia w Unii Europejskiej.

Bezrobocie ogółem w latach 2003-2004 nie zmieniło się istotnie w poszczególnych krajach. W 2004 r. w UE wynosiło 9\%. Największe bezrobocie było w Polsce $(18,8 \%)$, na Słowacji $(18,0 \%)$ oraz w Hiszpanii i na Litwie (po 10,8\%). Najniższe było natomiast w Luksemburgu $(4,2 \%)$, Norwegii $(4,4 \%)$ oraz Austrii i Irlandii (po 4,5\%).

Stopa bezrobocia wśród młodych osób, mających 15-24 lata, wyniosła w UE na koniec 2004 roku 18,2\%. Największe bezrobocie w tej grupie osób zanotowano w Polsce $(39,5 \%)$, na Słowacji $(32,3 \%)$ i w Hiszpanii $(22,0 \%)$, najniższe w Danii $(8,2 \%)$, Irlandii $(8,3 \%)$ i w Austrii $(9,7 \%)$.

Tab. 1. Odsetek gospodarstw domowych mających dostęp do internetu w domu

\begin{tabular}{|c|c|c|c|c|c|}
\hline Kraj Rok & 2000 & 2001 & 2002 & 2003 & 2004 \\
\hline Unia Europejska & : & : & : & : & 42 \\
\hline Belgia & 20,2 & 34,7 & 40,9 & $:$ & $:$ \\
\hline Czechy & 8 & 11 & 16 & 15 & $:$ \\
\hline Dania & 45,3 & 58,9 & 56 & 64 & 69 \\
\hline Niemcy & 13,6 & 37,9 & 46 & 54 & 60 \\
\hline Estonia & 7 & 9,8 & $:$ & : & 31 \\
\hline Grecja & 5,8 & 11,7 & 12 & 16 & 17 \\
\hline Hiszpania & 9,6 & 23,4 & 17 & 28 & 34 \\
\hline Francja & 12,9 & 26,2 & 23 & 31 & 34 \\
\hline Irlandia & 17,5 & 46,2 & 47,9 & 36 & 40 \\
\hline Włochy & 19,2 & 32,9 & 34 & 42 & 34 \\
\hline Cypr & 14,0 & 20,0 & 24 & 29 & 53 \\
\hline Łotwa & $:$ & 2,3 & 3 & $:$ & 15 \\
\hline Litwa & 2,3 & 3,2 & 4 & 6 & 12 \\
\hline Węgry & 2,6 & : & $:$ & $:$ & 14 \\
\hline Holandia & 46,1 & 58,5 & 58 & 59 & : \\
\hline Austria & 16,9 & 46,2 & 33 & 37 & 45 \\
\hline Polska & 5,1 & 7,7 & 11 & 14 & 26 \\
\hline Portugalia & 8,4 & 23,4 & 16 & 22 & 26 \\
\hline Słowenia & 21 & 24 & $:$ & $:$ & 47 \\
\hline Finlandia & 28,2 & 48,1 & 44 & 47 & 51 \\
\hline Szwecja & 47,5 & 64,3 & 64,2 & $:$ & $:$ \\
\hline Wielka Brytania & 24,4 & 46,5 & 50 & 55 & 56 \\
\hline Norwegia & 52 & 62,2 & $:$ & 60 & : \\
\hline Turcja & $:$ & $:$ & $:$ & $:$ & 7 \\
\hline
\end{tabular}

Źródło: opracowanie własne na podstawie Eurostatu. 
Zatem Polska jest krajem o zdecydowanie największej stopie bezrobocia ogółem i wśród osób mających 15-24 lata. Z tej najmłodszej grupy pracobiorców, część ma skończone studia wyższe. Istnieje sezonowa zależność stopy bezrobocia, zmieniającą się w kolejnych kwartałach wśród absolwentów studiów wyższych. W'śód tych, którzy mają 15-24 lata, w trzecim kwartale 2004 roku, najwieksza była na Słowacji $(33,6 \%)$, a następnie w Polsce $(33,0 \%)$ i w Belgii $(26,8 \%)$, najniższa natomiast w Wielkiej Brytanii $(8,8 \%)$, Szwecji $(9,4 \%)$ i Austrii $(10,1 \%)$. Zarówno w Polsce, jak i na Słowacji około $1 / 3$ absolwentów szkół wyższych jest więc bezrobotnych.

\section{Dostęp do internetu i jego i wykorzystanie}

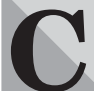

zy możliwe jest polepszenie sytuacji na rynku pracy przy wykorzystaniu internetu? Szanse uzależnione sa przede wszystkim od dostępności tego narzędzia (tabela 1).

Dostep gospodarstw domowych do internetu wzrasta we wszystkich krajach, w kolejnych analizowanych latach. Na koniec 2004 roku, średnio w UE dostęp miało $42 \%$ gospodarstw domowych. Największy dostęp maja one w Danii (69\%), Niemczech (60\%) i w Wielkiej Brytanii (56\%). Najmniejszy natomiast w Turcji (7\%), na Litwie (12\%) i na Węgrzech (14\%). W Polsce dostęp ma 26\% gospodarstw, co sytuuje Polskę zdecydowanie poniżej średniej unijnej.

Istotna dla rynku pracy może być częstość korzystania $\mathrm{z}$ internetu. Odpowiednie dane są przedstawione w tabeli 2 .
W przypadku osób mających 16-24 lata, w 2004 roku, średnio w UE z internetu przynajmniej raz w ostatnim tygodniu korzystało $61 \%$ osób, z czego najwięcej w Szwecji (92\%), Islandii (91\%) i Finlandii (88\%), a najmniej w Turcji (22\%), Grecji i Irlandii (po $35 \%$ ). W Polsce co druga osoba, w tej grupie wiekowej, skorzystała z tego narzędzia (tabela 2). Analizujac korzystanie $\mathrm{z}$ internetu przynajmniej raz na trzy miesiące osób w wieku 16-24 lata, można zauważyć, że czyni to zdecydowanie większy odsetek niż w ciagu tygodnia. W UE $82 \%$ osób w wieku 16-24 lata korzysta $\mathrm{z}$ internetu przynajmniej raz $\mathrm{w}$ ciagu trzech miesięcy, przy czym najwięcej osób w Szwecji (95\%), Islandii (94\%) i w Słowenii (93\%), a najmniej w Polsce (75\%), Wielkiej Brytanii (78\%) i na Łotwie (78\%). W Polsce więc ta grupa wiekowa korzysta rzadziej niż $\mathrm{w}$ analizowanych krajach.

Spośród studentów, przynajmniej raz w tygodniu z internetu korzystało w 2004 roku w UE 74\% osób, przy czym najwięcej w Islandii (96\%), Szwecji (94\%) i Finlandii (93\%), a najmniej w Turcji (44\%), Grecji $(46 \%)$, Polsce i we Włoszech (po 62\%). Przynajmniej raz w ostatnich trzech miesiącach w UE korzystało z internetu $86 \%$ studentów, z czego najwięcej w Szwecji (98\%), Islandii (97\%), Estonii i Finlandii (po 96\%), natomiast najmniej w Polsce $(77 \%)$, na Węrzech (80\%) i na Łotwie (81\%). Zatem również w tej grupie osób Polska należy do krajów o najniższym wykorzystaniu internetu.

Jedna z możliwości wykorzystania internetu jest kształcenie. W tabeli 3 przedstawiono dane dotyczace wykorzystania internetu do kształcenia formalnego.

Tab. 2. Odsetek osób regularnie korzystających z internetu

\begin{tabular}{|c|c|c|c|c|c|c|c|c|}
\hline \multirow{3}{*}{ Kraj } & \multicolumn{4}{|c|}{$\begin{array}{c}\text { Przynajmniej raz } \\
\text { w ciągu ostatniego tygodnia }\end{array}$} & \multicolumn{4}{|c|}{$\begin{array}{c}\text { Przynajmniej raz } \\
\text { w ciągu ostatnich trzech miesięcy }\end{array}$} \\
\hline & \multicolumn{2}{|c|}{ 16-24 lata } & \multicolumn{2}{|c|}{ studenci } & \multicolumn{2}{|c|}{ 16-24 lata } & \multicolumn{2}{|c|}{ studenci } \\
\hline & 2003 & 2004 & 2003 & 2004 & 2003 & 2004 & 2003 & 2004 \\
\hline UE (25) & - & 61 & - & 74 & - & 82 & - & 86 \\
\hline UE (15) & 59 & 64 & 68 & 77 & 83 & 83 & 88 & 89 \\
\hline Czechy & 42 & - & - & - & 70 & - & 71 & - \\
\hline Dania & 80 & 82 & 89 & 89 & 87 & 89 & 93 & 93 \\
\hline Niemcy & 72 & 78 & - & 84 & 86 & 86 & - & 89 \\
\hline Estonia & - & 75 & - & 89 & - & 92 & - & 96 \\
\hline Grecja & 33 & 35 & 45 & 46 & 87 & 84 & 88 & 83 \\
\hline Hiszpania & - & - & - & - & - & - & 82 & - \\
\hline Irlandia & 30 & 35 & 42 & - & 79 & - & 82 & - \\
\hline Włochy & 41 & 47 & 52 & 62 & 89 & 80 & 93 & 83 \\
\hline Cypr & - & 55 & - & 73 & - & 86 & - & 90 \\
\hline Łotwa & - & 54 & - & 64 & - & 79 & - & 81 \\
\hline Litwa & - & 63 & - & 77 & - & 88 & - & 89 \\
\hline Luksemburg & 81 & 78 & 90 & 84 & 90 & 88 & 94 & 90 \\
\hline Węgry & - & 53 & - & 70 & - & 80 & - & 80 \\
\hline Austria & 60 & 69 & 77 & 89 & 90 & 89 & 95 & 96 \\
\hline Polska & - & 50 & - & 62 & - & 75 & - & 77 \\
\hline Portugalia & 47 & 54 & 71 & 80 & 84 & 85 & 85 & 87 \\
\hline Słowenia & - & 66 & - & 82 & - & 93 & - & 95 \\
\hline Finlandia & 85 & 88 & 92 & 93 & 89 & 92 & 95 & 96 \\
\hline Szwecja & 92 & 92 & 92 & 94 & 95 & 95 & 98 & 98 \\
\hline Wielka Brytania & 60 & 65 & 80 & 84 & 73 & 78 & 84 & 90 \\
\hline Islandia & 90 & 91 & 98 & 96 & 93 & 94 & 99 & 97 \\
\hline Norwegia & 85 & - & 91 & - & 90 & - & 94 & - \\
\hline Turcja & - & 22 & - & 44 & - & 81 & - & 83 \\
\hline
\end{tabular}

Źródło: opracowanie własne na podstawie Eurostatu. 
Tab. 3. Odsetek osób wykorzystujących internet do formalnego kształcenia (w szkołach i uczelniach o sformalizowanym systemie ocen i stopni kształcenia)

\begin{tabular}{|l|c|c|c|c|c|c|c|c|}
\hline \multirow{4}{*}{ Kraj } & \multicolumn{3}{|c|}{$\begin{array}{c}\text { Przynajmniej raz } \\
\text { w ciągu ostatniego tygodnia }\end{array}$} & \multicolumn{3}{c|}{ Priągu ostatnich trzech miesięcy } \\
\cline { 2 - 9 } & $\mathbf{1 6 - 2 4}$ lata & \multicolumn{2}{c|}{ studenci } & \multicolumn{2}{c|}{$\mathbf{1 6 - 2 4}$ lata } & \multicolumn{2}{c|}{ studenci } \\
\cline { 2 - 9 } & $\mathbf{2 0 0 3}$ & $\mathbf{2 0 0 4}$ & $\mathbf{2 0 0 3}$ & $\mathbf{2 0 0 4}$ & $\mathbf{2 0 0 3}$ & $\mathbf{2 0 0 4}$ & $\mathbf{2 0 0 3}$ & $\mathbf{2 0 0 4}$ \\
\hline UE (15) & - & - & - & - & - & - & 63,6 & - \\
\hline Dania & 33,9 & 45,4 & 42,0 & 57,5 & 36,7 & 49,2 & 44,0 & 60,3 \\
\hline Niemcy & 46,6 & 56,9 & 91,0 & 78,4 & 55,1 & 62,1 & 94,4 & 83,5 \\
\hline Estonia & - & 50,8 & - & 71,8 & - & 62,8 & - & 78,1 \\
\hline Grecja & 24,2 & 26,5 & 36,6 & 38,2 & 64,4 & 64,4 & 72,0 & 69,4 \\
\hline Hiszpania & - & - & - & - & - & - & 34,5 & - \\
\hline Irlandia & 15,1 & 19,7 & 28,4 & - & 39,4 & - & 55,5 & - \\
\hline Cypr & - & 28,3 & - & 40,7 & - & 44,4 & - & 50,3 \\
\hline Lotwa & - & 29,5 & - & 39,6 & - & 43,1 & - & 50,3 \\
\hline Litwa & - & 61,4 & - & 77,0 & - & 85,4 & - & 89,0 \\
\hline Luksemburg & 62,1 & 31,7 & 76,5 & 38,8 & 69,1 & 36,1 & 79,6 & 41,4 \\
\hline Węgry & - & 39,5 & - & 60,6 & - & 59,5 & - & 69,4 \\
\hline Austria & 24,3 & 27,9 & 50,0 & 60,5 & 36,5 & 35,8 & 61,5 & 64,9 \\
\hline Polska & - & $\mathbf{1 4 , 8}$ & - & $\mathbf{2 0 , 3}$ & - & $\mathbf{2 2 , 4}$ & - & $\mathbf{2 5 , 1}$ \\
\hline Portugalia & 22,3 & 24,6 & 42,5 & 47,3 & 39,9 & 38,7 & 51,0 & 51,7 \\
\hline Słowenia & - & 32,5 & - & 45,7 & - & 45,6 & - & 53,3 \\
\hline Finlandia & 65,1 & 67,4 & 84,5 & 87,7 & 68,7 & 70,2 & 87,4 & 90,4 \\
\hline Szwecja & 14,4 & 10,4 & 21,6 & 15,1 & 14,8 & 10,7 & 22,9 & 15,6 \\
\hline Wielka Brytania & 45,8 & 43,9 & 89,8 & 81,9 & 55,8 & 52,8 & 94,5 & 87,4 \\
\hline Islandia & 10,8 & 9,7 & 12,9 & 16,4 & 11,2 & 10,0 & 13,1 & 16,5 \\
\hline Norwegia & 7,3 & - & 14,2 & - & 7,7 & - & 14,7 & - \\
\hline Turcja & - & 13,2 & - & 34,1 & - & 49,6 & - & 63,8 \\
\hline
\end{tabular}

Źródło: opracowanie własne na podstawie Eurostatu.

Tab. 4. Odsetek osób, które wykorzystały internet w celu polepszenia swoich szans na rynku pracy (np.: składanie aplikacji, zdobywanie informacji o pracodawcach itd., z wykluczeniem kształcenia, dokształcania i innych form edukacji)

\begin{tabular}{|c|c|c|c|c|c|c|c|c|}
\hline \multirow{3}{*}{ Kraj } & \multicolumn{4}{|c|}{$\begin{array}{c}\text { Przynajmniej raz } \\
\text { w ciągu ostatniego tygodnia }\end{array}$} & \multicolumn{4}{|c|}{$\begin{array}{c}\text { Przynajmniej raz } \\
\text { w ciągu ostatnich trzech miesięcy }\end{array}$} \\
\hline & \multicolumn{2}{|c|}{ 16-24 lata } & \multicolumn{2}{|c|}{ studenci } & \multicolumn{2}{|c|}{ 16-24 lata } & \multicolumn{2}{|c|}{ studenci } \\
\hline & 2003 & 2004 & 2003 & 2004 & 2003 & 2004 & 2003 & 2004 \\
\hline UE (15) & - & - & - & - & - & - & 15,4 & - \\
\hline Czechy & 0,7 & - & - & - & 1,2 & - & 0,2 & - \\
\hline Dania & 7,2 & 4,2 & 7,5 & 4,7 & 7,8 & 4,6 & 7,8 & 4,9 \\
\hline Niemcy & 17,2 & 20,3 & - & 20,0 & 20,3 & 22,2 & - & 21,3 \\
\hline Grecja & 9,6 & 11,0 & 12,0 & 15,2 & 25,6 & 26,8 & 23,6 & 27,6 \\
\hline Hiszpania & - & - & - & - & - & - & 8,9 & - \\
\hline Irlandia & 7,6 & 5,3 & 12,1 & - & 19,8 & - & 23,5 & - \\
\hline Cypr & - & 4,0 & - & 5,7 & - & 6,3 & - & 7,0 \\
\hline Łotwa & - & 9,5 & - & 12,0 & - & 13,9 & - & 15,2 \\
\hline Luksemburg & 11,7 & 22,1 & 11,3 & 24,4 & 13,0 & 25,1 & 11,8 & 26,0 \\
\hline Węgry & - & 4,2 & - & 0,2 & - & 6,4 & - & 0,2 \\
\hline Austria & 3,5 & 2,4 & 3,9 & 1,8 & 5,2 & 3,1 & 4,7 & 1,9 \\
\hline Polska & - & 0,7 & - & $\mathbf{0 , 5}$ & - & $\mathbf{1 , 0}$ & - & 0,6 \\
\hline Portugalia & - & 2,5 & - & - & - & 4,0 & - & - \\
\hline Słowenia & - & 2,6 & - & 3,0 & - & 3,6 & - & 3,5 \\
\hline Finlandia & 4,5 & 2,6 & 4,4 & 3,7 & 4,7 & 2,7 & 4,6 & 3,8 \\
\hline Szwecja & 4,9 & 1,8 & 7,2 & 1,2 & 5,1 & 1,9 & 7,6 & 3,8 \\
\hline Wielka Brytania & 29,9 & 21,8 & 26,3 & 28,5 & 36,5 & 26,3 & 27,7 & 30,4 \\
\hline Islandia & 3,2 & 5,0 & 4,9 & 10,6 & 3,3 & 5,1 & 5,0 & 10,6 \\
\hline Norwegia & 1,1 & - & 1,5 & - & 1,2 & - & 1,6 & - \\
\hline Turcja & - & 2,3 & - & 4,3 & - & 8,5 & - & 8,1 \\
\hline
\end{tabular}

Źródło: opracowanie własne na podstawie Eurostatu. 
Do formalnego kształcenia, osób mających 16-24 lata i korzystających z internetu przynajmniej raz w ostatnim tygodniu, najwięcej było w Finlandii $(67,4 \%)$, na Litwie $(61,4 \%)$ i w Niemczech $(56,9 \%)$, a najmniej w Islandii $(9,6 \%)$, Szwecji $(10,4 \%)$, Turcji $(13,2 \%)$ i w Polsce $(14,8 \%)$. W tej grupie wiekowej, przynajmniej raz w ostatnich trzech miesiaccach $\mathrm{z}$ internetu najwięcej osób korzystało na Litwie $(85,4 \%)$, w Finlandii $(70,2 \%)$ i w Grecji $(64,4 \%)$, a najmniej w Islandii (10\%), Szwecji (10,7\%) i w Polsce (22,4\%).

Do formalnego kształcenia, przynajmniej raz w ostatnim tygodniu, najwięcej studentów wykorzystuje internet w Finlandii $(87,7 \%)$, Wielkiej Brytanii $(81,9 \%)$ i w Niemczech $(78,4 \%)$, a najmniej w Szwecji $(15,1 \%)$, Islandii $(16,4 \%)$ i w Polsce $(20,3 \%)$. Przynajmniej raz w ostatnich trzech miesiącach najwięcej studentów skorzystało z internetu w Finlandii $(90,4 \%)$, na Litwie (89\%) i w Wielkiej Brytanii $(87,4 \%)$, a najmniej w Szwecji (15,6\%), Islandii $(16,5 \%)$ i w Polsce $(25,1 \%)$.

Polska zatem należy do krajów o najniższym wykorzystaniu internetu do kształcenia formalnego.

Ważnym czynnikiem zwiększającym szanse na zadowalającą pracę jest możliwość i chęć do pozaformalnego dokształcania się. Informacje o dokształcaniu, jak i nieraz samo szkolenie, może odbywać się za pomoca internetu.

W roku 2004 w części krajów nastąpił wzrost wykorzystania internetu do szkolen, a w innych zmniejszył się. Wśród osób majacych 16-24 lata, najwięcej korzystajacych przynajmniej raz w ciagu ostatniego tygodnia z internetu było w Niemczech (41,1\%), Wielkiej Brytanii $(20,6 \%)$ i Grecji $(17,0 \%)$, a najmniej w Islandii (1,3\%), Polsce $(1,4 \%)$ i Finlandii $(2,0 \%)$. W tej grupie wiekowej, przynajmniej raz w ciagu ostatnich trzech miesięcy, najwięcej osób korzystało $\mathrm{z}$ internetu do celów dokształcania w Niemczech (44,9\%), Grecji (41,2\%) i Wielkiej Brytanii (24,7\%), a najmniej w Islandii (1,3\%), Polsce i Finlandii (po 2,1\%).

Spośród studentów, najwięcej w ostatnim tygodniu wykorzystało internet do potrzeb związanych ze szkoleniem w Niemczech $(48,2 \%)$, Wielkiej Brytanii $(32,8 \%)$ i Grecji $(23,9 \%)$, a najmniej w Islandii $(0,9 \%)$, Polsce $(1,8 \%)$ i w Danii $(2,6 \%)$. Natomiast w ostatnich trzech miesiacach najwięcej studentów z opisywanego instrumentu skorzystało w Niemczech (51,4\%), Grecji (43,5\%) i w Wielkiej Brytanii (35,0\%), a najmniej w Islandii $(0,8 \%)$, Polsce $(2,2 \%)$ i Danii $(2,7 \%)$.

Można więc wysunąc wniosek, że w analizowanych grupach, stopień wykorzystania internetu w zakresie szkoleń i dokształcania jest w Polsce jednym z najniższych w Europie.

Ostatnią kwestią jest wykorzystanie internetu do wszelkich działań pracobiorców, poza kształceniem, wpływających na lepszą sytuację na rynku pracy (tabela 4).

Najwięcej osób w wieku 16-24 lat, w ciągu ostatniego tygodnia, wykorzystywało internet do polepszenia swojej sytuacji na rynku pracy w 2004 r. w Luksemburgu (22,1\%), Wielkiej Brytanii $(21,8 \%)$ i Niemczech $(20,3 \%)$, a najmniej w Polsce $(0,7 \%)$, Szwecji $(1,8 \%)$ i Turcji $(2,3 \%)$. Natomiast w ostatnich trzech miesiacach, najwięcej osób skorzystało w analizowanym zakresie w Grecji (26,8\%), Wielkiej Brytanii $(26,3 \%)$ i Luksemburgu (25,1\%), a najmniej w Polsce $(1,0 \%)$, Szwecji $(1,9 \%)$ i w Finlandii $(2,7 \%)$.
Najwięcej studentów w ciągu ostatniego tygodnia, wykorzystywało internet do polepszenia swojej sytuacji na rynku pracy w 2004 r. w Wielkiej Brytanii (28,5\%), Luksemburgu $(24,4 \%)$ i w Niemczech $(20,0 \%)$, a najmniej na Węgrzech $(0,2 \%)$, w Polsce $(0,5 \%)$ i w Szwecji (1,2\%). W ostatnich trzech miesiącach najwięcej skorzystało w Wielkiej Brytanii $(30,4 \%)$, Grecji $(27,6 \%)$ i w Luksemburgu $(26,0)$, a najmniej na Węgrzech $(0,2 \%)$, w Polsce $(0,6 \%)$ i w Austrii (1,9\%).

Polska zatem ponownie należy do krajów o najmniejszym wykorzystaniu internetu, tym razem do polepszenia sytuacji na rynku pracy przez poszczególnych pracobiorców.

\section{Podsumowanie}

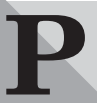

odsumowując powyższe analizy, można stwierdzić, że Polska jest krajem o niskiej dostępności internetu dla gospodarstw domowych. Problemem częściowo z tym związanym jest bardzo słabe wykorzystanie w Polsce internetu do kształcenia, dokształcania i zwiększania swoich szans na rynku pracy w inny sposób, np. poprzez szybszą komunikację z potencjalnym pracodawcą. Możliwe, że dotyczy to szczególnie osób żyjących na obszarach o największej stopie bezrobocia rejestrowanego, gdzie wiele gospodarstw domowych nie posiada środków na zaspokojenie podstawowych potrzeb, a tym bardziej na kupno komputera i korzystanie z internetu. Być może byłyby lepsze możliwości wzrostu zatrudnienia osób z tych regionów, gdyby mogły one korzystać z internetu do szukania ofert pracy, komunikowania się z ewentualnymi pracodawcami, poszukiwania informacji o szkoleniach i możliwościach przekwalifikowania itd.

Jednakże, co warte podkreślenia, również studenci w Polsce w znacznie mniejszym stopniu niż studenci w innych krajach europejskich korzystaja z internetu w celu kształcenia, dokształcania się oraz poszukiwania kontaktów z ewentualnymi pracodawcami. Wydaje się, że jest to zjawisko niekorzystne dla aktywności tej grupy osób na rynku pracy.

Problemem zatem do rozważenia i wykazania aktywności, być może dla polityki społeczno-gospodarczej państwa, ale też uczelni, szkó1, pracodawców itd. jest zwiększenie dostępu do internetu osób indywidualnych i lepsze jego wykorzystanie do poprawy sytuacji pracobiorców na rynku pracy, szczególnie w regionach o dużym ubóstwie i szczególnie wysokiej stopie bezrobocia.

dr Wojciech Jarecki Katedra Mikroekonomii Wydział Nauk Ekonomicznych i Zarządzania Uniwersytetu Szczecińskiego

*) Część danych obejmuje osoby w wieku 15-24 lata, a część 16-24 lata.

BIBLIOGRAFIA

[1] GÓRA M., Trwale wysokie bezrobocie w Polsce. Wyjaśnienia i propozycje, ,Ekonomista” $\mathrm{nr} 1 / 2005$.

[2] KABAJ M., Program przeciwdziatania ubóstwu i bezrobociu, IPiSS, Warszawa 2000.

[3] KRYŃSKA, E., SUCHECKA J., SUCHECKI B., Prognoza podazy i popytu na pracę $w$ Polsce do roku 2010, IPiSS, Warszawa 1998

[4] KWIATKOWSKI E., Bezrobocie. Podstawy teoretyczne, PWN, Warszawa 2002.

[5] SKÓRSKA A., Młodzież na rynku pracy $w$ Polsce $i$ Uni Europejskiej, Wydawnictwo Wyższej Szkoły Bankowej, Poznań 2004. 